\title{
How Leadership \\ Should Be Exercised \\ in Early Childhood Education?
}

¿Cómo se debe ejercer el liderazgo en la educación de la Primera Infancia?

Research article | Artículo de investigación

Received on: July 31st 2019 Accepted on: Frebruary10th 2021 Available online from: September 2021

doi: 10.11144/Javeriana.m14.hlsb

Piedad Cabrera-Murcia pcabrerm@uahurtado.cl

Universidad Alberto Hurtado, Chile (D) ORCID: https://orcid.org/0000-0003-1122-5232

To cite this article | Para citar este artículo

Cabrera-Murcia, P. (2021). How leadership should be exercised in early childhood education? magis, Revista Internacional de Investigación en Educación, 14, 1-24. doi: 10.11144/Javeriana.m14.hlsb 


\section{Abstract}

This research article gathers the perceptions about how directors and pedagogical teams understand and experience leadership within five Junji preschools in Chile. Data were collected for from five semi-structured interviews and a participant observation. Findings suggest three forms of exercising leadership: pedagogical, supervisory, and administrative. In all cases, there are the same threats to leadership. The study uncovers some personal skills and characteristics common to the ways of leading. The article also highlights the context as a key element to the exercise of leadership, and the importance of modeling collaborative cultures, which consider the centrality of children's learning in preschool education.

\section{Keywords}

Early childhood education; Chile; leadership; qualitative analysis

\section{Resumen}

Este artículo de investigación recoge las percepciones sobre cómo directores y equipos pedagógicos entienden y experimentan el liderazgo en cinco centros preescolares ubicados en Junji, Chile. Se recopilaron datos de cinco entrevistas semi-estructuradas y una observación participativa. Los hallazgos sugieren tres formas de ejercer el liderazgo: pedagógica, supervisora y administrativa. En todos los casos, existen las mismas amenazas al liderazgo. El estudio descubre algunas habilidades y características personales comunes a las formas de liderazgo. El artículo también destaca el contexto como un elemento clave para el ejercicio del liderazgo y la importancia de modelar culturas colaborativas, que consideran la centralidad del aprendizaje de los niños en la educación preescolar.

\section{Palabras clave}

Educación de la primera infancia; Chile; liderazgo; análisis cualitativo 
Article description | Descripción del artículo

Research article derived from the project of Pedagogical

leadership and concepts about teaching and learning in

Early Childhood Education managers of the Center for the

Development of Educational Leadership (CEDLE) in 2018.

\section{Introduction}

The notion of leadership has been extensively investigated in relation to the elementary and middle school levels, but very little in early childhood education. At elementary and middle school levels, there is a consensus about the director-effect on educational quality, probably due to the focus extension of their performance: from organizational management to the pedagogical aspect (Leithwood \& Riehl, 2005; Robinson, 2010; Uribe, 2005). In the latter, actions are focused on the teaching-learning processes, a key dimension in describing good leadership practices (Anderson, 2010; Leithwood \& Riehl, 2005).

In line with these investigations, the director figure in early childhood education is considered the key to ensuring that education raises the learning and achievement standards of children (Klevering \& McNae, 2018; Nupponen, 2005; Rodd, 1997; Siraj-Blatchford \& Manni, 2006). Similarly, a transit from a hierarchical vision of leadership, to one that is based on the interdependence of roles, such as teamwork, is being recognized as a way of understanding the structure of leadership (Heikka \& Waniganayake, 2011; Rodd, 2006; Spillane, 2016).

In Chile, research on leadership in early childhood education is still emerging, although studies have reported that this is an important aspect to consider when assessing the quality of education systems (Britto et al., 2011). A study carried out in our country on social representations about educational quality in early childhood education shows that, although the need for a balance between gestion and pedagogical leadership tasks is revealed in order to deliver a quality education, in practice there is a greater tendency to perform gestion tasks (Centro de Políticas Comparadas de Educación, 2015). For that reason, indicators of process quality, such as interactions between adults and children, effective leadership, and pedagogical aspects, continue to be at the expense of structural variables such as infrastructure (Agencia de Calidad de la Educación, 2015). 
In Chile, there is national research on directors' leadership (Pastén, 2017; Venegas, 2016), but there is no a clear account on possible configurations that can emerge when leading a preschool, what are the characteristics or skills that a director must possess, and whether there are threats that hinder leadership. Whit this in mind the present study, consisting of an intentional sample of five public preschools located in the Metropolitan Region of Santiago de Chile, intends to answer these questions based on the understanding and experience of leadership from directors, early childhood educators, and assistants of each preschool.

\section{Context of the Study}

Early childhood education in Chile is defined as an educational level that "fully cares for children from birth to primary education entry, not being mandatory for it; with the purpose of favoring comprehensive development and relevant and significant learning in children according to the curricular bases, and where the family has an irreplaceable role" (Decreto con Fuerza de Ley n. ${ }^{\circ}$ 2, december 16th, 2009). There are two types of institutions that currently serve the education for children ages zero to six: day-care centers and preschool (34\%) and primary schools (66\%). In the first segments, the providers are the Junji, Integra and private schools. This study focuses on the Junji as a holder of day-care centers and preschool institutions.

The suitable staff in early childhood education in Chile is made up of:

1. educators with a degree in early childhood education that involves initial training of 4 or 5 years at a university. Educators are responsible for leading the teaching processes in the classroom. In Chile, the concept of "educators" is used to differentiate it from a teacher or traditional practitioners, thus referring to the educator as a professional who seeks to highlight comprehensive education in children. In this study, the term educators is used because it is part of their identity, differentiating themselves from teachers at the primary and secondary levels.

2. assistants, these women hold a diploma awarded either by a tertiary education institution or by a secondary school. Assistants support the comprehensive care of children in the classroom.

3. early childhood directors, who are also professional educators and therefore hold a professional degree in early years' education. They have the role of leading pedagogical processes and management of the administration of the early childhood education service. 


\section{Theoretical Framework}

The study of leadership in the field of early childhood education has increased due to the attention that has been put on how to provide quality learning opportunities for children (Klevering \& McNae, 2018). Recent research identifies different perspectives on early childhood leadership. According to the Cooperrider \& Whitney (2005) study, there is appreciative leadership. This, established as a democratic and participatory process, improves the positive emotions that impact the cohesion of the group and the emotional development of the members of the community. A more recent focus points out leadership characterized by high levels of collaboration and teamwork and a distributed leadership which can be carried out by any member of the organizational context (Gronn, 2008, cited in Fonsén, 2014; Siraj-Blatchford \& Manni, 2006).

In Heikka \& Waniganayake's study (2011), pedagogical leadership focused on the learning of children and the teaching-learning processes and can be distributed to all members of the community. Heikka (2014), in this context, proposes that both the pedagogical and the distributed perspectives are intertwined, pointing to several people involved in working with the curriculum and pedagogical improvement.

Leadership is not limited to a single person, although some studies have pointed out the importance of the suitability of those who exercise the role of director (Rodd, 2006). According to Thornton et al. (2009), it is necessary to consider addressing the organizational structure and culture of the preschool, since these can influence the emergence of a common understanding of leadership.

According to the pedagogical leadership theory, its power lies in the sharing of vision, knowledge about pedagogical quality, reflection on processes and management skills within an organization (Fonsén, 2014). Pedagogical leadership is a community phenomenon that guides pedagogical and management practices in preschools. Leadership capital is shared in the community (Sergiovanni, 1998, cited in Fonsén, 2014). That is, the director is the bearer of the goals of the preschool and makes sure that they are shared and meaningful for the team. Supporting the staff in the development of quality practices is reaffirmed thanks to theoretical knowledge and a vision on the pedagogy that the center leader should have (Hujala et al., 2016; Klevering \& McNae, 2018).

Fonsén \& Keski-Rauska (2018) in this context propose that early childhood leadership should focus its work on the learning and well-being of children. In this case, the director must build the conditions to motivate a 
culture of interaction between the pedagogical team, and trust and empowerment to ensure quality education in early childhood. Recent research also allows us to identify key elements that characterize leadership in early childhood education which are detailed below.

\section{Strong Emphasis on Context}

Studies confirm the need to consider the context when describing the meanings around leadership (Fonsén, 2013; Hujala, 2004; Hujala, 2013). This would be defined by what happens at a macro level -the legislation- and at a micro level-dispositions, within the children's center. From the contextual leadership model proposed by Nivala (1999, cited in Hujala, 2004), the context is revealed within a preschool as a cultural system in which educational foundations, mission, as well as parents, children, professionals, authorities, society and their culture are contemplated. Thus, "the interactions and cooperation between the different actors, at different levels of leadership, are particularly significant for its success" (Hujala, 2013, p. 52).

The uniqueness of organizational contexts may favor or hinder the emergence of pedagogical leadership (Fonsén, 2013; Heikka et al., 2011. Thus, in the early childhood education context, vision and mission are elements that configure the contents of the tasks and responsibilities assumed by the leadership (Hujala et al., 2016; Southworth, 2004, cited in Siraj-Blatchford \& Manni, 2006). Clarifying interdependently the mission and vision of the preschool favors the creation and development of leadership structures and tasks (Hujala, 2013).

\section{Children at the Center of Pedagogical Leadership}

Focusing the actions of leadership on children and their needs, favors their learning, as well as the professionalization of those who teach (Heikka, 2014). The centrality of the child is considered a key element that should be reflected in the actions of preschool leaders (Heikka \& Waniganayake, 2011). Children's visibility in the discourse mitigates the confusion that preschool directors may have when referring to management, administration or leadership (Hujala \& Eskelinen, 2013; Klevering \& McNae, 2018).

Fonsén (2013), in his study, identifies four key aspects in characterizing pedagogical leadership: having adequate resources (equipment, time, materials, etc.); personal management skills (which allows educators to reach the distinctive pedagogical commitments of the center); pedagogical skills (pedagogical knowledge in their disciplinary field, as well as tools that allow them to lead the pedagogical aspect), and the feeling of appreciation for their work from higher administration. The first three aspects emphasize the centrality of children's learning in pedagogical leadership. 


\section{Team of Educators Supporting Leadership}

If we consider that preschool leadership is strongly influenced by the context, we could refer to it as a social system of collective rather than hierarchical relations (Aubrey et al., 2013). In this regard, professional relationships and feelings of satisfaction would translate into a sense of identity and the educator's professional value towards their organization (Colmer, 2015).

In Finland, for example, it was found that sharing leadership tasks with educators was perceived as effective if pedagogical quality, children's learning and achievement-oriented pedagogy are ensured (Heikka et al., 2018). Directors in this study delegated to their team processes of evaluation, planning and assurance of the objectives of the center, and distribution of curricular functions. For them, sharing pedagogical leadership with educators brings them closer to daily classroom practice, an element missing from their role.

Another key element that characterizes the collective work, indicated in this study, is the consideration of the allocated time for annual planning meetings, in addition to regular meetings. In this space, topics of interest to the team were shared, as well as pedagogical guidelines that oriented the teaching exercise. Also, weekly team meetings were held, which addressed pedagogical topics such as planning, evaluation and knowledge about children (Heikka et al., 2018).

Some reported studies point out that the diminished presence of the director was associated with less cohesion among educators, diversity of interpretation about situations and lower satisfaction with feedback received (Colmer, 2015). These finding contrasted with studies that suggested leadership as a social system of collective relations, where it is emphasizing the role of the director as a support in the exercise of pedagogical leadership (Colmer, 2015; Heikka et al., 2018)

\section{Profile of the Leader in Early Childhood Education}

The quality of environments in early childhood education increases in relation to the qualifications of the leaders, with higher qualifications linked to higher quality (Siraj-Blatchford \& Manni, 2006). In Finland, Japan and Singapore, training in the care and education of young children is important, highlighted by Singapore having a diploma in leadership, in addition to teaching qualifications; and in Japan, the emphasis is on practical skills and experience developed. In these countries, the person who leads does not carry out pedagogical practices inside the classroom. Their focus is on tasks that ensure the quality of processes for the children who attend the preschools (Hujala et al., 2016). 
Directors must have theoretical knowledge and a pedagogical vision to involve staff in the development of quality practices; guiding organizational culture and teamwork, as well as improving staff skills (Heikka et al., 2018, Hujala \& Eskelinen, 2013; Hujala et al., 2016; Rodd, 2006; Siraj-Blatchford \& Manni, 2006). Their focus is on child learning, and management and leadership are dimensions that run parallel in a preschool (Waniganayake et al., 2000). There are studies that show a rejection of the notion of leadership as part of professional identity (Krieg et al., 2014).

Some studies also suggest other key points for leading early childhood educational success: working on the development of a shared vision which benefits everyone (Ang, 2011); having communication skills, to promote mutual support, to manage continuous training (Hujala \& Eskelinen, 2013; Waniganayake et al., 2012); and establishing and maintaining trust relationships within the team (Klevering \& McNae, 2018).

The knowledge, skills and attitudes that enrich leadership are reflected in those functions or tasks performed by the director. Having a vision and being able to articulate it in practice, establishing links between the center and the community, developing a community of apprentices and giving leadership to children, are responsibilities and tasks that were identified as relevant when characterizing leadership in early childhood education ( $\mathrm{Ha}$ therley \& Lee, 2003, cited in Mujis et al., 2004).

Another aspect that characterizes the leader's profile at this level is the distinction between pedagogical leadership and human resources management (Hujala et al., 2016). In the first aspect, actions such as the development of educational practices are highlighted and the consideration of human relationships and administrative management from the educational achievements' perspective stand out. In the second aspect, the importance is centered in the supervision of the team, examining procedures, introducing new practices, finding a balance between the staff needs and the quantity and quality of it, and the staff labor towards meeting the goals. In countries such as Finland and Singapore, secretarial tasks, hiring substitute personnel, infrastructure maintenance and small purchases, that is, daily administrative tasks, took the third place (Hujala et al., 2016).

Although there is a body of knowledge such as the one described above, the evidence of these studies also suggests that the tasks from the director's role remain unclear, blurring —almost always - the pedagogical leadership in preschool (Hujala, 2013; Klevering \& McNae, 2018). The directors doubt how pedagogical leadership can be implemented, although in their interview data in Fonsén's study this is a strong topic (Fonsén, 2013). In the midst of this dilemma, the need to discover, from the directors themselves, how they understand pedagogical leadership from daily 
work, the assignment of tasks and associated times to ensure the quality of teaching is evident (Fonsén, 2013).

\section{Methodology}

Forms of leadership that occur within five preschools in Santiago de Chile were investigated in this research. The question that guided this study was: How do directors and pedagogical teams understand and experience leadership within the preschools themselves? Together with this question, we explored: What are the threats that impact on leadership development, as well as the skills and personal characteristics of preschool directors' leaders?

A qualitative, descriptive-interpretive methodology was used, because it is a lens that allows us to understand, deconstruct, connect and give meaning to perceptions of leadership from the directors, early childhood educators and assistants. A multiple case study was used, as a method that allowed the investigation of the leadership phenomenon within a real context, seeking to understand the uniqueness of the contexts and to be able to establish comparisons between cases, but without intending to generalize (Stake, 1998; Yin, 2003).

\section{Participants}

This study is an intentional sample, not a probabilistic one. It describes five preschool institutions directly administered by the National Board of Preschool Institutions, in the Metropolitan Region of Santiago, Chile. The cases were selected at convenience, from the set of preschools that were located at an advanced level of the Quality Management Model of preschool education in 2015, and with a distinctive pedagogical project.

After that, and following the criteria indicated by Stake (1998), which refer to selecting cases that maximize learning opportunities, these were focused as common criteria for a new choice of the initial set: preschools where the director had more than two years of experience directing the preschool and had been trained in early childhood education and leadership at the time of the study. The selection of early childhood educators and assistants was made by the director, from the construction of a visual map that graphically represented who went along with her in her task of leading the preschool.

In total, 25 preschool education professionals participated in this study. Considering that this is a highly feminized profession, it is not surprising that all of them were women. In each case, five people were interviewed, namely: one director, two early childhood educators and two assistants, who were informed of the purpose of this study, as well as 
ethical and confidentiality safeguards with the information. All of them agreed to participate voluntarily and gave their consent.

\section{Instruments}

The techniques used for the collection of information were: semi-structured interviews with the 25 participants of the study and participant observation of a team meeting, which allowed a deep understanding in relation to institutional routines (such as team meetings, training talks).

\section{Analysis of the Data}

The methodological procedures of Glaser \& Strauss (1967) grounded theory was used. This allows us an analytical process from which concepts, properties and dimensions are identified, until generating explanatory, dense, complex models, close to the one they are representing (Krause, 1996). To ensure the reliability and validity of the findings, actions such as: Clarification of the researchers' prejudices, double coding, and triangulation of perspectives from the participants' interview data were carried out (Flick, 2004), in such a way of counting on a coherent corpus to reflect the results of the investigation.

As Yin (2003) recommends, in this investigation, multiple sources of evidence were used that, in turn, allowed us to comply with the principle of triangulation of data to guarantee its validity. The semi-structured interviews with directors, early childhood educators and assistants and the participant observation of a team meeting, were the sources used in each case. Likewise, triangulation was also ensured in the analysis of the data collected from the inter-rater validation.

In this study, the data are recognized from the voices of the directors, educators, and assistants from the five preschools, thus using a triangulation of sources in order to increase the reliability and validity of the results. Two different interviewers collected the data, which were codified, independently, by three investigators from the field of education and sociology, who shared in their profile the training and experience in the educational area.

\section{Results}

Gathering information about understand and experience leadership from directors, and pedagogical teams, allowed the identification of three emerging issues: 1) ways to exercise leadership in the preschools, 2) threats that undermine the ways of leading, and 3) the skills and personal characteristics that the participants of this study recognize are in tune with the ways of leading. 


\section{Ways to Exercise Leadership in Preschools}

The first theme shows us the emergence of six key elements that configure different ways to exercise leadership in preschools, namely: Sharing the mission/vision and hallmark that gives identity to the preschool; working collaboratively; building positive relationships; processes that support the team, including continuous training; the consideration of evaluation as a tool that supports continuous improvement and construction of professional identity. The presence or absence of any of these elements, make up three leadership spotlights, namely: pedagogical, supervision and administrative (figure 1).

Figure 1

Six key elements that configure different ways to exercise leadership

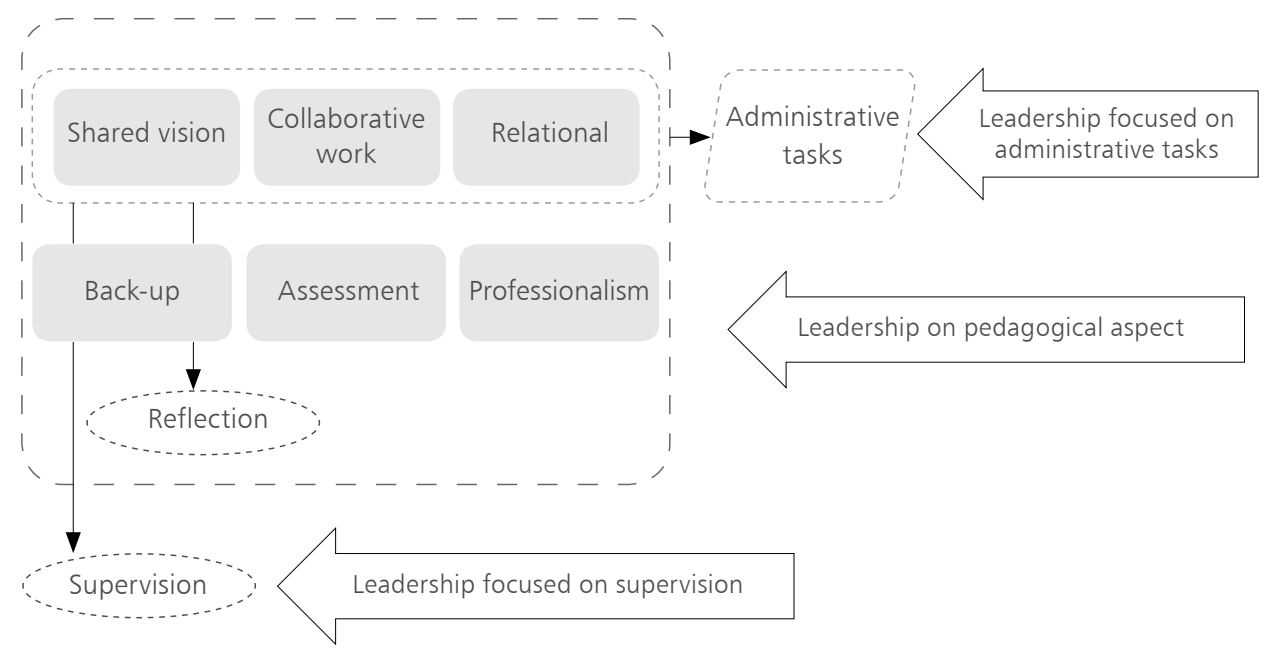

Source: Own source

In two of the case studies, leadership focused on the pedagogical aspect. For these directors, maintaining reflective processes with the team allows them to share an educative common project and the same meaning of teaching to learn in early childhood. Its curricular modalities is characterized by a way of teaching that enhances learning and development opportunities in children. The directors of case studies 1 and 4 remarked:

Our curricular modality is based on educational workshops, these workshops are installed from a long and arduous conversation that we had with the teams to be able to achieve this objective which is the leading role and the active role of the children where the child can be democratically involved [...] (director, case 1). 
We are in a constant analysis and one of those is how to make our vision of preschool even more transversal [...]. This has been a constant dilemma, because we believe that it is never enough [...]. Tomorrow we will have our learning communities [...]. We hope to build a strategy with the participation of all to strengthen it, to enhance the aspects that we consider weak (director, case 4).

For these directors, pedagogical leadership must include knowledge of pedagogy and the use of certain tools that permit them more possibilities for pedagogical discussions (Fonsén, 2013). Both directors use tools that support the reflection needed for them to engage the team in core tasks connected with the educative project in the preschool.

In both contexts, the teams recognize that the director empowers her team with confidence and acknowledges that everyone has their capabilities and can jointly move forward to a common goal. Educators and assistants at this preschool stated that:

We are distributing functions in relation to the competences and strengths of each of them (educator 1, case 1).

Here is a good work environment, when I arrived it was not so much, but now we are all rowing on the same side and it is because there is trust, we learned to know each other [...], but I think everything starts with the director. If the director were otherwise, I think it would be more difficult (assistant 2, case 4).

According to Klevering \& McNae (2018) effective leadership involves empowering others and developing a positive organizational culture. The data from the observations of the meetings in Case 1 and 4 confirm that the director develops a positive organizational culture that fosters positive relationships and supports processes of continuous improvement.

In this meeting there is a warm, welcoming, good treatment between assistants, educators, and director. She is kind to everyone, treats everyone equally. There is constant validation verbally and non-verbally by the director with her team (observation, June 1, 2018).

The director invites me to observe how the guests are being received, so that I can see how important this event is to the community. In this moment, an anxious assistant approaches and the director talk with her, give emotional closeness and calm, for that she empowers herself of task to be done on that day (observation, June 2, 2018). 
In these cases, data show that embedded in the pedagogical leadership of directors are recognition of the human capacities of educators and assistants. A strong relationship of trust is perceived by the team as effective for pedagogical quality in the preschool. Scholars like Hujala et al. (2016) frame that directors who implemented pedagogical leadership spend time on human relationships, improving and developing educational and teaching practices.

In two of the case studies the director had a focus on supervision and understood leadership exclusively as related to management. Teams that follow this way of leading, referred in their interview data to the supervision functions, commitment verification and pedagogical tasks of the directors. An educator's remark reaffirmed this:

[The director role is] organizing and coordinating rooms being appropriate, watching out the staff has a back-up in the rooms, [...]. The director is the head [...], she is the one who organizes and coordinates us, that is, we organize ourselves, but she is supervising that this organization is working and that everyone is doing their job properly (educator 2, case 5).

In case 2 one assistant said that director

organize and ensure that everything is being done, with the same frequency [...]. She gives us tasks, she also corroborate that one is doing things too [...]. For example I am in charge of the prevention plan and then, I have to go to his office so that we can see that (assistant, case 2).

For the directors in case study 2 and 5, supervising the agreements and keeping track of the committed actions is necessary to manage preschools. Likewise, these directors consider that distributing these functions in the team allows the weight of the tasks not to fall on a single person. This perspective is evident in following examples shown:

There are two assistants who supervise the work of all personnel. They supervise whether it was carried out with their level, too the work is divided so that at least one does not have the full weight (director, case 5).

I delegate responsibilities to her, and she does it very well, she handles some things very well because she has worked with me for 22 years (director, case 2).

Observation of team meeting showed in case 5 that the director's leadership focus was on supervision. In this space topics covered were supervised by director. For example, this excerpt is useful to characterize it: 
The director delegates an educator to talk about educational spaces. While she exposes, the director intervenes by clarifying the information given. [...] Another educator opens a debate on how to improve the learning environment in the classroom. This causes tense interactions. "Whose spaces, are they?" it was the kind of questions that were asked. The director intervenes and loud speech "that's right, let us be fair", "we are the children's role model" (observation, 10 august, 2018).

These findings showed a director's profile as a "supervising agent" of tasks and functions, results that contradict those reported in studies that emphasize the role of the director as support in the exercise of pedagogical leadership of educators (Colmer, 2015; Heikka et al., 2018).

The last type of leadership emerges with a focus on administrative tasks, which was present in one of the cases. Educators in this preschool point out that being a director involves carrying out a variety of management tasks that involve great responsibility. All tasks are concentrated on achieving structural variables in the preschool. An educator said:

When it was my turn to be here in the office, the truth is that there're so many things to do [...]: A father is coming who needs an interview, a child fell, there was an accident, something was missing in the kitchen, I don't know, it doesn't work a bathroom (educator 2, case 3).

One of the strongest aspects in team interviews in this preschool was the hierarchy concept. Participants used words like head, guide, when describe the work of director. The team considers that there is a hierarchy where there is a head, which guides and lead the preschool tasks. A comment from an educator points out: "She [the director] is obviously the one who leads [...], gives the guidelines for the work [...]. I consider that when everything is too horizontal, it does not work, for example, it does not work here in this preschool" (educator 2, case 3).

In this way of leading, there is an imbalance between structural and process variables. The director is overloaded with administrative actions, for example, addressing the specific needs of parents, supervising infrastructure work and carrying out staff replacements, due to the high rate of absenteeism of the pedagogical team. Tasks that sometimes must be reassigned to other educators of the institution. In the words of the participants:

[The director] spends a lot of time here at the office because she is constantly sending out information [...]. Sometimes we need extra meetings, and there she is, but to do that she is leaving aside her own job at the office, accumulating more work (educator, case 3). 
In this case, it was shown that contextual complexities can threaten the practice of pedagogical leadership. Tension between managing a centre and leading learning are key elements identified in another research (Klevering \& McNae, 2018). For example, the director in case three, pointed out: "[Leadership is] quite a difficult burden [...]. Sometimes the staff's coefficient is also not adequate for working with children. There are no medical-leave replacements, so the rest of the people overstress. It is about stress" (director, case 3).

\section{Threats that Undermine the Ways of Leading}

The study participants agreed that the excess administrative burden, as well as the high absenteeism rate for educators and assistants, meaning that directors are sometimes required to fulfill the role of the educator in the classroom, hinders the processes of continuous accompaniment that the director should perform with the team. For example, an educator of case study 1 affirmed that "the obstacles would be [...] medical leaves when you are not supposed to [...]. We can't get everyone to participate due to that factor and time" (educator 1, case 1).

Having little time to develop collaborative tasks together along with the director, on which to reflect upon the practice, on how to grant learning opportunities for a child, can become another threat that hinders pedagogical leadership. Assistants in the preschool outlined it like this: "The truth is that there is not much time [for feedback]" (assistant 1, case 3).

From the point of view of the participants, constant rotation of the pedagogical team in the preschools does not favor the shared construction of instances that extend children's learning and active development. In addition to the above, there is not enough time for participation in joint workspaces and excessive distribution of roles. The assistant in case 4, explains how not working together makes it difficult to share visions and strategies on how to support children to learn:

I finished with this project last year and I left with some of the children where I am now. Some of my other partners did not experience the project, so they do not have the project itself very focused, something that reflects upon the children (assistant 1, case 4).

Other threats to leadership are the traditional conceptions of learning and teaching of the pedagogical team or the lack of understanding or adherence to the formative values of preschool. This hinders the exchange of meanings and the collective effort to find optimal strategies for strengthening the learning process. A director pointed out: 
[In this preschool] there is an environmentalist project. Unfortunately, even in the previous meetings I told them "girls if you don't like it, you have to look closely at the preschool that you want to go, because there is an environmentalist seal here and you work with earth, you have to do it" (director, case 5).

Finally, in one of the cases, the director felt that she is not recognized at an institutional level for her professional competences. This perception of non-validation coincides with a leadership in which the focus is on administrative tasks.

\section{Skills and Personal Characteristics}

Necessary to Lead a Preschool

Exploring conceptions and understandings of leadership in the participants, provided information about their perceptions of the skills and personal characteristics necessary to lead a preschool. These characteristics are common across all cases studies and are outlined below.

\section{Ability to guide the educational community}

Participants recognized the director as a person with the ability to guide the team: "In this case, she has the clarity, the vision, the breadth of everything that an educational project should consider" (educator 1, case 1). Continually the directors stimulated their team to build enriched learning spaces for the children.

\section{Empathic ability}

All participants considered that empathic ability is a characteristic of directors. This is reflected in the following comments: "She always gives you the flexibility and has the ability to understand" (assistant 2, case 4); "I feel that she puts herself in the place of the educators" (educator 1, case 3). Educators and assistants felt supported, cared for and respected, regardless of the role they played in preschool.

\section{Communication}

This refers to the director's ability to listen to their team, try to reach agreements in the dialogue and show respect for different opinions. For example, one assistant remarked: "When I don't agree then she says 'if we can do this in the same way as you say, and you can include this' [...]. Ah, ok super [...]. She always listens to us" (assistant 2, case 5).

Directors too confirmed from their own practice, that communication is an ability necessary for leading preschools. For example, a director said: 
I believe that it is a fundamental part, to talk with people always from strengths [...]: "You have all these strengths, I congratulate you, you did very well, your children are delighted, you have no family complaints. However, some aspects should be improved" (director, case 1).

\section{Establish trusting relationships with the team}

The importance of trust is reflected in the directors' high ability to listen, to treat their team well, without imposing their ideas, but to collectively reflect and reach a consensus. One director said: "I think that if you allow your staff to be calm on a personal and emotional level, the girls, when I need them, they are always there" (director, case 5). From the observations of the meetings it is shown that directors build trusting relationships with teams. For example, the observation of case 4: "The director invites me to observe how they will receive the guests, because this celebration for community is important. At that moment, a very anxious assistant walks nearby, and the director calls her, contains and gives her calmness" (observation, June, 2018).

\section{Commitment to work}

The director has a genuine concern for the community that makes up the preschool. This translates into a strong commitment to the staff team, children, and community. As one assistant pointed out, "the director is in the room as well [...]. She is super collaborative in the classroom, in all acts. [...] She is with the children, she is super dynamic, as well" (assistant 2, case 2).

\section{Be motivating}

All participants described the capacity to motivate and to orient the team members, for example in the implementation of improvement actions. This is evident in the following examples: "The director encourages you" (assistant 1, case 1); "She is always open to our innovations" (educator 2, case 4); and "Motivates us to all this, makes us participate in everything" (educator 1 , case 5 ).

The interviews data showed in case 1 that director stand out for their high ability to reflect on their own pedagogical practices and include teams in the reflection process. For example, educators show how crucial the collaborative reflective practice is in relation to the educational project:

Our educational project is intercultural. At the beginning, it was an option of ours — family and staff- for Mapuche Culture. But actually, we have so many immigrants, then now more than an option is a need for cultural change and we can incorporate in our practices (educator 1, case 1). 
Leading change is crucial in leadership work, and this achievement occurs when the director shares a vision and includes the team in all reflexive process (Rodd, 2006, cited in Hujala \& Eskelinen, 2013).

In case study 1 , where the leadership focuses on the pedagogical aspect, the director highlighted a strong emphasis on reflective praxis processes in her undergraduate training, self-taught training processes, as well as professional experience from the different roles of her team (assistant and educator in the classroom). The director in case 1 explained her undergraduate training:

Look, I believe that my base - and I had not said that before- is what I was taught at university. [...] The aim of [university name] was to turn us into reflective and critical professionals of what we do. Reflective and critical. That is, I am constantly refining what I do. Will this work? It does not? Does it help children? Am I doing many things? (director, case 1).

\section{Discussion and Conclusions}

This study showed that, although all the directors, educators and assistants interviewed shared the centrality of children in their leadership, they differed in the ways of conceptualizing leadership in early childhood. These include pedagogical and management terms, and job descriptions that lack clarity and make it difficult to construct a clear definition of early childhood leadership.

This study confirms the need to consider the context when describing the meanings around leadership (Fonsén, 2013; Hujala, 2004; Hujala, 2013). In our study, the three ways of exercising leadership — pedagogical, supervisory, and administrative- are determined by how the context is configured in preschool. For example, if the context is characterized by numerous administrative tasks, this inhibit in the teams' the possibility of share the same meaning of teaching to learn in early childhood. In others, if the context is defined by the supervision of responsibilities assigned within the team, this action configures another way of leading of preschool.

We also found two cases that showed that leadership at this educational level requires actions that model a culture of collaboration, that favors children's learning. According to our study, in this context the ability to guide the educational community, set specific goals and be able to read the context in a systemic way, are distinctive abilities of a leader who plans and puts into action a pedagogical leadership.

Previous research into the role of the director highlights the importance of having defined the central tasks of the preschool to implement a pedagogical leadership (Fonsén, 2013; Fonsén et al., 2018). This result 
coincides with that obtained in case 1 of this study. For example, clarity in the assignation of curricular tasks such as planning and evaluating processes allows your team to mobilize their capacities for action for the benefit of a common project. In this case, the director promotes a culture of collaboration between the pedagogical team. Educators and assistants actively participate, they encourage interdependence and co-responsibility of tasks, with the purpose of creating learning opportunities for children in the preschool. These findings are consistent with those reported in other studies (Fonsén, 2014; Hujala et al., 2016; Southworth, 2004, cited in Siraj-Blatchford \& Manni, 2006).

Although there isn't a clear definition of preschool leadership, this research reinforces the characteristics valued as those of pedagogical leaders: reflection, having theoretical and pedagogical knowledge, as well as knowledge and skills for working with adults in the processes of reflective praxis. These aspects have been indicated as key to consider when talking about exercising leadership (Fonsén, 2014; Haile \& Hussien, 2017; Hujala et al., 2016; Klevering \& McNae, 2018; Organización para la Cooperación y el Desarrollo Económico, 2008; Waniganayake, 2010).

In addition to these two elements, our study showed that the director's ability to raise her skills to motivate, teach and lead her team towards common goals is key when building the path of her pedagogical leadership. Hence, personal abilities, such as the ability to guide the educational community are presented in this context of study as key facilitators in the process of leading preschools.

Collaborative work was identified as an emerging element in the analysis of the data, showing a more collective than hierarchical leadership outlook. In preschool education, working collaboratively is key, since there is talk of a pedagogical team made up of an educator and more than one assistant who supports the tasks that provide well-being and learning opportunities for children. In this sense, the interdependence of roles and teamwork are necessary to propose and lead experiences of meaningful learning in early childhood education. These results are consistent with research at the school and early childhood education (Fonsén et al., 2018; Heikka \& Waniganayake, 2011; Spillane, 2016).

The findings reinforce the need for training about how to lead pedagogically in preschool education. Likewise, training from old paradigms or the lack of professional skills to work in initial education, reported by some directors and educators of the cases reviewed, hinders the leadership of the director because there is no qualified staff that allows the opening and collective construction of continuous improvements in benefit of the well-being, learning and development of children. 
Our study shows that directors, in some of the cases studied, continue to fulfill administrative tasks, or pedagogical ones from the educator role in the classroom. These are negative influences for the group cohesion and for sharing a common goal (Colmer, 2015), which ultimately impacts the pedagogical proposals offered to children. This finding confirms what was found by previous studies in Chile, where the balance leans towards administrative management at the expense of the pedagogical aspect (Centro de Políticas Comparadas de Educación, 2015).

The findings of this research show that whoever leads preschools should adjust their leadership with a focus on the pedagogical aspect, where the centrality of the child mobilizes the agency of the team, as well as their professional development. A pedagogical leader who raises in their team capacities for action and continuous improvement has a conception of learning and active teaching at the base. They raise cognitive and attitudinal resources, where the construction of a mutual learning space is encouraged, together, for the benefit of a common project: providing quality learning opportunities in early childhood.

Finally, the limitations of the present study are related to the size of the sample, as well as the use of only participants from one of the institutions that provide, at the national level, early childhood education in Chile. Although the number of preschools - cases in this investigation - is greater than that used in national studies already reported, this is limited compared to the universe of preschools that are part of the public institution from which they were extracted. This last aspect can also be a limitation, since using cases of a single holder, of three working in the education of preschool children, can skew the results obtained.

Although the results of this type of study cannot be generalized, it is necessary to highlight that these can be guiding in the construction of educational policies, which ensure those conditions that favor the exercise of leadership with a focus on the pedagogical aspect in preschool institutions. This research suggests the importance of appropriately defining and communicating directors' roles for enhance pedagogic leadership. Likewise, adequately resourcing for their work is an important aspect to consider of organizational design. How such support can be provided at scale and how directors craft an effective role in absent such support entails further research.

As a projection and challenge of this study, there is a need to delve into the cases, considering the learning achievements of the children who attend the preschools. A look at this variable allows the assessment of whether the focus on the pedagogical aspect has a direct effect on these or, on the contrary, if there are other variables not observed in this first 
study which contribute to characterize the leadership at this educational level. Likewise, a recommendation for future research in this field includes being able to collect information from other stakeholders that, at the national level, provide preschool education, in order to reaffirm or expand the significance of the leadership obtained in this study.

\section{Agradecimientos}

Special Thanks to Junji for opening the possibility of conducting research on the subject, and particularly to the teams from the participating kindergartens.

\section{About the author}

Piedad Cabrera-Murcia is a teacher and researcher in the area of teaching and learning in early childhood, as well as in higher education, Universidad Alberto Hurtado, Chile. She is currently the director of the Early Childhood Education Career, Faculty of Education.

\section{References}

Agencia de Calidad de la Educación. (2015). El liderazgo del equipo directivo en enseñanza básica y su relación con indicadores de desarrollo personal y social de su establecimiento. https://bibliotecadigital.mineduc.cl/bit stream/handle/20.500.12365/4573/Liderazgodirectivoyrelacion.pdf?sequen ce $=1$ \&isAllowed $=y$

Anderson, S. (2010). Liderazgo directivo: claves para una mejor escuela. Psicoperspectivas, 9(2), 34-52. https://www.psicoperspectivas.cl/index.php/ psicoperspectivas/article/view/127/141

Ang, L. (2011). Leading and Managing in the Early Years: A Study of the Impact of a NCSL Programme on Children's Centre Leaders' Perceptions of Leadership and Practice. Educational Management Administration \& Leadership 40 (3), 289-304.

Aubrey, C., Godfrey, R. \& Harris, A. (2013). How do they manage? An investigation of early childhood leadership. Educational Management Administration and Leadership, 41(1), 5-29. https://doi.org/10.1177/1741143212462702

Britto, P. R., Yoshikawa, H. \& Boller, K. (2011). Quality of early childhood development programs in global contexts: Rationale for investment, conceptual framework, and implications for equity. Social Policy Report, 25(2). https:// files.eric.ed.gov/fulltext/ED519240.pdf

Centro de Políticas Comparadas de Educación (CPCE). (2015). Estudio Calidad Educativa en Educación Parvularia: Experiencias Internacionales y Representaciones sociales Nacionales. Informe final. Autor. http://archivos.agen ciaeducacion.cl/Informe_Estudio_Calidad_Educacion_Parvularia_2015.pdf 
Colmer, K. (2015). Leading professional development and learning in early childhood centres: A social systems perspective. In M. Waniganayake, J. Rodd \& L. Gibbs (Eds.), Thinking and learning about leadership. Early childhood research from Australia, Finland and Norway (pp. 32-48). Community Child Care Co-operative (NSW).

Cooperrider, D. \& Whitney, D. (2005). A positive revolution in change: Appreciative inquiry. https://www.researchgate.net/publication/237404587_A_Pos itive_Revolution_in_Change_Appreciative_Inquiry

Decreto con Fuerza de Ley (DFL) n. ${ }^{\circ}$ 2. (December 16th, 2009). Fija texto refundido, coordinado y sistematizado de la Ley n. 20.370 con las normas no derogadas del Decreto con Fuerza de Ley n. ${ }^{\circ}$ 1, de 2005. https://www.bcn. $\mathrm{cl} /$ leychile/navegar?idNorma $=1014974$

Flick, U. (2004). Introducción a la investigación cualitativa. Morata.

Fonsén, E. (2013). Dimensions of pedagogical leadership in early childhood education and care. In E. Hujala, M. Waniganayake \& J. Rodd (Eds.), Researching Leadership in Early Childhood Education (pp. 181-192). Tampere University Press.

Fonsén, E. (2014). Pedagoginen johtajuus varhaiskasvatuksessa [Pedagogical leadership in Early Childhood Education/Akateeminen Väitöskirja] [Doctoral dissertation, Tampere University Press]. https://trepo.tuni.fi/bitstream/ handle/10024/95050/978-951-44-9397-3. pdf? sequence=1\&isAllowed=y

Fonsén, E. \& Keski-Rauska, M.-L. (2018). Varhaiskasvatuksen yhteinen johtajuus vastakohtaisten diskurssien valossa. Työelämän Tutkimus, 16(3), 185-200. https://journal.fi/tyoelamantutkimus/article/download/85232/44213/

Glaser, B. \& Strauss, A. (1967). The discovery of grounded theory. Aldine.

Gronn, P. (2008). The future of distributed leadership. Journal of Educational Administration, 46(2), 141-158. https://doi.org/10.1108/09578230810863235

Haile, Y. \& Hussien, B. (2017). Practice and challenges of preschool leadership and management in public and private kindergarten in Jijiga City administrations. Journal of Humanities and Social Science, 22(12), 74-83. http:// www.iosrjournals.org/iosr-jhss/papers/Vol.\%2022\%20lssue12/Version-7/ L2212077483.pdf

Harris, A. (2012). Distributed leadership: Implications for the role of the principal. Journal of Management Development, 31(1), 7-17. https://doi.org/ 10.1108/02621711211190961

Hatherley, A. \& Lee, W. (2003). Voices of early childhood leadership. New Zealand Journal of Educational Leadership, 18, 91-100.

Heikka, J. (2014). Distributed pedagogical leadership in early childhood education [Doctoral dissertation, University of Tampere]. Acta Electrónica Universitatis Tamperensis, 1392.

Heikka, J., Halttunen, L. \& Waniganayake, M. (2018). Perceptions of early childhood education professionals on leadership in Finland. Early Child Development and Care, 188(2), 143-156. https://doi.org/10.1080/03004430.20 16.1207066

Heikka, J. \& Waniganayake, M. (2011). Pedagogical leadership from a distributed perspective within the context of early childhood education. International Journal of Leadership in Education, 14(4), 499-512. https://doi.org/10.108 0/13603124.2011.577909 
Hujala, E. (2004). Dimensions of leadership in the childcare context. Scandinavian Journal of Educational Research, 48(1), 53-71. https://doi. org/10.1080/0031383032000149841

Hujala, E. (2013). Contextually defined leadership. In E. Hujala, M. Waniganayake \& J. Rodd (Eds.), Researching leadership in early childhood education (pp. 47-60). Tampere University Press.

Hujala, E. \& Eskelinen, M. (2013). Leadership tasks in early childhood education. In E. Hujala, M. Waniganayake \& J. Rodd (Eds.), Researching leadership in early childhood education (pp. 213-234). Tampere University Press.

Hujala, E., Eskelinen, M., Keskinen, S., Chen, Ch., Inoue, Ch., Matsumoto, M. \& Kawase, M. (2016). Leadership task in early childhood education in Finland, Japan, and Singapore. Journal of Research in Childhood Education, 30(1), 406-421. https://doi.org/10.1080/02568543.2016.1179551

Klevering, N. \& McNae, R. (2018). Making sense of leadership in early childhood education: Tensions and complexities between concepts and practices. Journal of Educational Leadership, Policy \& Practice, 33(1), 5-17. https:// doi.org/10.21307/jelpp-2018-002

Krause, M. (1996). Criterios de calidad para estudios cualitativos. Documento de trabajo, Primer Curso de Capacitación en Técnicas Cualitativas para Equipo de Alcohol y Drogas, Ministerio de Salud [Unpublished document].

Krieg, S., Smith., K. \& Davis, K. (2014). Exploring the dance of early childhood educational leadership. Australasian Journal of Early Childhood, 39(1), 73-80. https://doi.org/10.1177/183693911403900110

Leithwood, K. \& Riehl, C. (2005). What we know about successful leadership. In W. Firestone \& C. Riehl (Eds.), A new agenda: Directions for research on educational leadership (pp. 22-47). College.

Mujis, D., Aubrey, C., Harris, A. \& Briggs, M. (2004). How do they manage? A review of the research on leadership in early childhood. Journal of Early Childhood Research, 2(2), 157-169. https://doi.org/10.1177/1476718X04042974

Nivala, V. (1999). Pa"iva"kodin Johtajuus [Leadership in a child care center; in Finnish]. Acta Universitatis Lapponiensis, 25.

Nupponen, H. (2005). Liderazgo y gestión de servicios de cuidado infantil: factores contextuales y su impacto en la práctica [Tesis doctoral sin publicar]. Universidad de Tecnología de Queensland.

Organización para la Cooperación y el Desarrollo Económico (OCDE). (2008). Mejorar el liderazgo escolar. Política y prácticas. OECD Publishing. http:// www.oecd.org/education/school/44374937.pdf

Pastén, V. C. (2017) Liderazgo educativo ejercido por directoras de jardines infantiles públicos de Chile [Tesis de maestría sin publicar]. Pontificia Universidad Católica de Chile.

Robinson, V. M. J. (2010). From instructional leadership to leadership capabilities: Empirical findings and methodological challenges. Leadership and Policy in Schools, 9(1), 1-26. https://doi.org/10.1080/15700760903026748

Rodd, J. (1997) Learning to be leaders: Perceptions of early childhood professionals about leadership roles and responsibilities. Early Years, 18(1), 40-46. https://doi.org/10.1080/0957514970180108

Rodd, J. (2006). Leadership in early childhood. Allen \& Unwin. 
Sergiovanni, T. J. (1998). Leadership as pedagogy, capital development and school effectiviness. International Journal of Leadership in Education, 1(1), 37-46. http://dx.doi.org/10.1080/1360312980010104

Siraj-Blatchford, I. \& Manni, L. (2006). Effective leadership in the early years sector. The ELEYS Study. Institute of Education University of London.

Southworth, G. (2004). Primary school leadership in context: leading small, medium and large sized schools. Routledge Falmer/Taylor \& Francis.

Spillane, J. (mayo, 2016). Presentación de El liderazgo distribuido en educación. Fundamentos y consecuencias [Video]. YouTube. https://www.youtube.com/ watch? $v=$ hhm0DYRq-uM

Stake, R. (1998). Investigación con estudio de casos. Morata.

Strauss, A. L. \& Corbin, J. (1990). Basics of qualitative research: Grounded theory procedures and techniques. Sage.

Thornton, K., Wansbrough, D., Clarkin-Phillips, J., Aitken, H. \& Tamati, A. (2009). Conceptualising leadership in early childhood education in Aotearoa New Zealand. New Zealand Teachers Council.

Uribe, M. (2005). El liderazgo docente en la construcción de la cultura escolar de calidad: un desafío de orden superior. Revista PRELAC, (1), 106-115. http://unesdoc.unesco.org/Ulis/cgi-bin/ulis. pl?catno $=144742 \&$ set $=49 E F C$ 06D_3_13\&gp $=1 \&$ lin $=1$

Venegas, N. (2016). Competencias de liderazgo pedagógico desarrolladas por el programa Quik ${ }^{\circledR}$ en directoras de salas cunas y jardines infantiles de Valparaíso, un estudio de caso [Tesis de maestría sin publicar]. Pontificia Universidad Católica de Chile.

Waniganayake, M. (2010). Leadership in child center: Is it just another job? Special Issue: Management and Leadership. Australian Journal of Early Childhood, 28(1).

Waniganayake, M., Cheeseman, S., Fenech, M., Hadley, F. \& Shepherd, W. (2012). Leadership: Context and complexities in early childhood education. Oxford University Press.

Waniganayake, M., Morda, R. \& Kapsalakis, A. (2000). Leadership in childcare centers: Is it just another job? Australasian Journal of Early Childhood, 25(1), 1-6.

Yin, R. (2003). Case study research: Design and methods (4a. ed.). Sage. 